\title{
Uma caixa de surpresas: nota sobre a volta do romance de 30
}

\author{
Alfredo Bosi
}

RESUMO: Ultrapassadas as leituras redutoras, em geral dogmáticas, a melhor crítica universitária começa a olhar de novo, e como se fosse pela primeira vez, o texto como lugar de tensões que envolvem o eu e o outro, a intuição e as coisas do mundo, o desejo e as pressões da sociedade a caixa de surpresas que é o romance de 30 ainda está longe de ter sido cabalmente explorada.

PALAVRAS-CHAVE: Romance de 30; novo olhar; pressões sociais

ABSTRACT: After overcoming reductive readings, generally dogmatic, the best academic criticism begins, as if for the first time, to look at the text as a place of tensions involving the self and the other, intuition and things of the world, desire and the pressures of society - the box of surprises which is the romance of 30 is still far from being fully exploited.

KEYWORDS: Novels from the 30 's; new look; social pressures 
Um dossiê sobre o romance brasileiro de 30, organizado por estudiosos de literatura brasileira, é sinal auspicioso de que o ensino das letras está voltando a abrir-se para um dos filões mais ricos de nossa narrativa. Muito do que se criou naquele decênio arriscava-se a cair na penumbra do esquecimento de que sofre a rotina universitária.

Um prenúncio feliz dessa renovada atenção dirigida àqueles narradores e a algumas de suas obras-primas deu-se com a edição da obra exemplar de Luís Bueno, Uma história do romance de 30 , publicada conjuntamente pelas editoras da usP e da Unicamp. ${ }^{1}$ A partir desse estudo fundamental, que toma a análise das obras como primeiro passo para chegar a uma visão de conjunto, o leitor do romance de 30 tem um guia seguro para avaliar o momento talvez mais fecundo da narrativa brasileira.

O chamado "romance de 30 " a rigor não se restringiu a esse tempo por tantos motivos decisivo como período de transformação da sociedade e do Estado nacional. Os que nele estrearam ainda escreveriam ao longo do decênio de 40 quando se assinala a lenta passagem para outras formas de escrita ficcional. Mas, ao lado de uma cronologia mais aberta do que supõe aquele rótulo, o que nos interessa é a novidade crítica (que o livro de Luís Bueno trabalha intensamente): a surpresa de ver entrelaçadas quase em cada romance as dimensões sociais e psicológicas que a historiografia corrente tende a separar.

Creio que, nesse particular, vem se operando uma revisão cognitiva do fenômeno literário. A dimensão representativa ou, lato sensu, mimética, que às vezes parece recobrir inteiramente o projeto de uma literatura de intenção realista, não se concretiza na trama ficcional de forma autônoma, independente dos vetores construtivo e expressivo, inerentes a toda obra de arte. O que se denomina genericamente com o termo "realidade" converte-se, movido pela dinâmica da escrita, em uma fusão singular de objeto visto e sujeito que o vê, observação e sentimento, imaginação reprodutiva e imaginação criativa, tela e perspectiva, mensagem e forma.

Nada melhor do que abrir ao acaso uma página de São Bernardo, ou de Fogo morto, ou de Menina morta, ou de Os ratos, para surpreender a formação poliédrica da escrita ficcional que, em cada uma dessas obras-primas, revela ora a face visível do objeto, ora o pathos com que a penetra o seu criador, ora a estrutura que serve de armação ao processo narrativo. Daí decorre a necessidade de compor um discurso crítico atento a cada uma dessas faces, cuja combinação acaba produzindo um efeito singular, que outrora se denominava estilo do autor.

1. Bueno, Luís. Uma história do romance de 30. São Paulo: Edusp; Campinas: Editora Unicamp, 2006. 
Vejo com satisfação que, ultrapassadas por dentro as leituras redutoras, em geral dogmáticas, a melhor crítica universitária começa a olhar de novo, e como se fosse pela primeira vez, o texto como lugar de tensões que envolvem o eu e o outro, a intuição e as coisas do mundo, o desejo e as pressões da sociedade. E tenho a conviç̧ão de que a caixa de surpresas que é o romance de 30 ainda está longe de ter sido cabalmente explorada.

Tome-se, por exemplo, a organização narrativa de Os ratos, atentamente analisada por Luís Bueno no ensaio citado. O narrador em terceira pessoa, que recobre os pensamentos do pobre diabo Naziazeno Barbosa, marca, pelo uso intensivo de aspas e grifos, o distanciamento que o separa da mente do protagonista. Aqui, a representação da instância social não é efetuada mediante um processo transparente ou homogêneo: realiza-se pela armação dupla, só aparentemente unitária, da perspectiva adotada.

O trabalho analítico da mímesis ganha complexidade não só em virtude daqueles procedimentos gráficos insólitos. A representação da coisa objetiva (os percalços da personagem dentro das malhas da sua classe social) dá-se dentro de um clima existencial de alienada humilhação e medo insone, suspensos de modo intermitente por fios de esperança de obter o dinheiro devido ao leiteiro.

Componentes estruturais da narrativa, como o espaço e o tempo, o protagonista e sua relação com o outro são configurados por fora e por dentro, ao acaso das circunstâncias. Assim, há cercas vivas entre a casa de Naziazeno e os vizinhos próximos, aí "as sombras têm uma frescura que cheira a ervas miúdas"; mas, se o jardim parece dadivoso exalando perfumes silvestres, "um ou outro olhar de criança fuzila através das frestas das cercas". A natureza será neutra e inofensiva, dando sombra e frescor a devedores e credores. Mas a condição objetiva não é a mesma para uns e outros. Os que não devem não temem, estão rindo e bebem cachaça em frente do armazém. Naziazeno deve cinquenta e três mil réis ao leiteiro que há bem pouco os cobrara aos berros. No percurso para a repartição, tudo são olhares feitos de curiosidade maligna, "aqueles dois olhos sabidos, de verruma, olhos devassadores".

O dia ainda é ameno, a cor da luz do sol é diversa de manhã, ao meio-dia, à tardinha. "Neste momento é dourada, as sombras são azuis." No entanto, o olhar do outro altera a qualidade do lugar que a natureza tende a preservar. Volta a ameaça proferida pelo leiteiro à porta de sua casa: "Lhe dou mais um dia!". A obsessão da dívida é o pesadelo acordado que assombra o espaço cotidiano e investe o cerne do seu tempo. A primeira hora da manhã que precede a abertura do expediente ainda é capaz de promessas, um empréstimo do diretor, quem sabe. O relógio da torre é o contraponto 
de cada situação: agora marca pouco mais de oito horas. É obsedante essa marcação miúda, em minutos, que se estende do terceiro ao quarto capítulo. Cada avanço do ponteiro traz um alento que logo cede ao desânimo, ao desejo de evasão e a uma nova expectativa de obter o dinheiro. "Pago o leiteiro, o mundo recomeçará, novo, diferente." O tempo do relógio mecaniza no seu tique-taque regular o andamento impassível da natureza que se move pelo dia afora até o sol declinar. Mas a jornada de Naziazeno não caminha no bojo dessa neutralidade das horas que se sucedem alheias ao seu drama. Ao contrário, a sua experiência a um só tempo social e subjetiva fica paralisada pelos malogros de conseguir o empréstimo e esvaziada pela indiferença do diretor e dos colegas de repartição. A hora avança, o sol da tarde move-se ora queimando, ora ofuscando, mas o pobre devedor continua manietado à dívida, metáfora cruel da sua condição. $\mathrm{O}$ tempo que passa é seu inimigo. "Não sabe como encherá a tarde. O seu 'nevoeiro' só lhe permite ver um raio muito pequeno, muito chegado. Àquela hiperaguda fixação num ponto, em que estivera até então, como é bom suceder um período vazio... vazio...."

No centro da narrativa constrói-se o espaço-tempo do jogo: a roleta, o imprevisto, o acaso, o tudo-ou-nada que se dará como avesso da rotina implacável de Naziazeno. O jogo, com a sua potencialidade de sorte, será a saída bem-vinda, embora aleatória, momentânea, de uma carência que, tudo indica, selará para sempre o destino do nosso pobre-diabo. Mas agora ele pode pagar ao leiteiro. Agora poderá encarar os olhos de seta dos vizinhos e dos colegas de trabalho. Agora não receará mais o olhar desamparado da mulher.

Mas o narrador não nos deixará aliviados, postos em sossego. As notas colocadas sobre a mesa, junto à panela onde o leiteiro deverá apanhá-las, estarão sendo roídas pelos ratos na calada da noite? O pesadelo acordado vara os últimos capítulos. Como separar a descrição minudente dos ruídos noturnos e a insônia feita de sobressalto, pura agonia? Como separar a coisa e o sujeito?

Presentificação, construção e expressão interpenetradas fazem da escrita de Dyonelio Machado um torniquete para o leitor, mesmo que este nunca haja partilhado da experiência sufocante do protagonista. Assim o que parece apenas uma situação particular, a imagem sofrida da baixa classe média na Porto Alegre dos anos 30, ascende à condição do humano no horizonte da empatia do leitor com Naziazeno Barbosa. ${ }^{2}$

2. Sobre a amplitude das interpretações possíveis do romance, remeto o leitor ao belo posfácio de Davi Arrigucci Jr. à terceira edição de Os ratos. São Paulo: Planeta, 2004. 
Termino lembrando a afirmação incisiva com que Merleau-Ponty abre o seu luminoso ensaio, $O$ olho e o espírito: "A ciência manipula as coisas e renuncia a habitá-las". 3 A literatura age diversamente, habita as coisas que representa, pois não só as exprime, enquanto sentimento do mundo, como as reconstitui pela força da linguagem.

Alfredo Bosi é professor titular aposentado e professor emérito de literatura brasileira da Universidade de São Paulo

3. Merleau-Ponty, Maurice. O olho e o espírito. Tradução de Paulo Neves e Maria Ermelina Pereira. São Paulo: Cosac Naify, 2004, p. 13. 